\title{
Overview of IPR Practices for Publicly-funded Technologies
}

\author{
Jayant A. Sathaye \\ Lawrence Berkeley National Laboratory \\ University of California \\ Berkeley, CA \\ Elmer C. Holt \\ Office of Policy and International Affairs \\ Office of Petroleum and Transportation Fuels \\ US Department of Energy \\ Washington, DC \\ Stephane De La Rue du Can \\ Lawrence Berkeley National Laboratory \\ University of California \\ Berkeley, CA
}

31 October 2005

This work was partially supported by the Climate Technology Initiative, US Department of Energy, under contract number DE-AC03-76SF00098. 


\section{Acknowledgements}

The authors would like to thank Ms. Cheryl Fragiadakis, Head, Technology Transfer Department, Lawrence Berkeley National Laboratory, for information and keen insights on US laws and regulations and LBNL policy regarding technology transfer, Ms. Elizabeth Blackburn, NRCan, Govt. of Canada and Dr. Yang-hoon Sonn, Incheon University for information about technology transfer policies and programs and their evolution in Canada and the Republic of Korea respectively. 


\section{Overview of IPR Practices for Publicly-funded Technologies ${ }^{1}$}

\section{Introduction:}

The term technology transfer refers to a broad set of processes that cover the flows of know-how, experience, and equipment for mitigating and adapting to climate change amongst different stakeholders, including governments, the private sector, and financial institutions, environmental organizations, and research/education institutions. (Metz et al. 2000). Transfer encompasses diffusion of technologies and technology cooperation across and within countries, and forms one element of the overarching goal of the Climate Convention (UNFCCC) to stabilize greenhouse gas concentrations in the atmosphere.

Governments devote varying amounts toward sponsoring or in some manner supporting a broad array of research activities pursuing a diverse set of outcomes ranging from medicine to energy and the environment. These activities can take place within government-owned facilities, private companies, or universities or some combination thereof. Such pursuits may result in the identification of a patentable technology or process, as well as copyrightable computer programs or other publications worthy of intellectual property rights (IPRs) protection. Although the precise arrangements vary from country to country, there is a high degree of commonality in the manner in which the property rights to these publicly-sponsored results are assigned. Except in the case of "pure research" the property rights are assigned to one or more of the participants to the research process; government, university, private contractor, etc. For example, captured under the "pure research" classification is genomic sequence data that is immediately shared with the public at large and to a significant extent climate data resulting from government-sponsored research is placed in the public domain. The results of this review are intended to inform the Expert Group on Technology Transfer as called for by 2005 programme of work.

While the purpose of this paper is not to examine the connections between the Climate Convention and other treaties, it is worth noting that the issue of IP has been considered widely

\footnotetext{
${ }^{1}$ This overview paper was prepared in response to the UNFCCC Expert Group on Technology Transfer’s 2005 programme of work, May 2005.
} 
under the negotiations of the World Trade Organization (WTO). The Agreement on TradeRelated Aspects of Intellectual Property Rights (TRIPS) emerged from the Uruguay Round of trade negotiations completed in 1994. The Final Act of these negotiations created the WTO and set out rules - the WTO Agreements including TRIPS - with which members of the WTO have to comply. TRIPS requires all WTO Members to provide minimum standards of protection for a wide range of IPRs including copyright, patents, trademarks, industrial designs, geographical indications, semiconductor topographies and undisclosed information. There are continuing discussions in World Intellectual Property Organization (WIPO) aimed at further harmonization of the patent system across countries, which may supersede TRIPS.

To better understand the issues associated with publicly-financed/ publicly-owned technologies versus those in the public domain, the OECD in 2000-01 conducted a review and survey of several countries' procedures for handling the rights and title to intellectual property. The detailed survey collected data and information on patenting and licensing at public research organizations (PROs). ${ }^{2}$ Its goals were to (i) document and assess the legal and regulatory frameworks for commercializing IP generated with public research funds, (ii) measure and analyze the patenting and licensing activities of PROs in member and selected non-member countries, and (iii) identify areas for policy action. (OECD, 2003) The above survey noted an important trend regarding the ownership of IP. The granting of ownership of the IP to the research organization and ensuring that benefits are shared with inventors has emerged as common practice in many OECD countries. As noted in a recent report, the management of IPR has evolved from an Open Science model to a Licensing Model (EC 2004). In the selected countries that we report on in this overview, institutional ownership of the IP is the norm, and as we describe in the US and Republic of Korea (ROK) examples, several stakeholders may share in its monetary rewards (Table 1). The EC report also provides data from a survey of licensing income derived from technology transfer in Canada, the USA, and UK (Table 2) (UNICO-NUBS 2001). This informal paper builds on material in the OECD report and combines it with countryspecific examples and readily available recent information and data about operating practices in selected countries.

\footnotetext{
${ }^{2}$ Public research organizations (PROs) include universities, and non-university entities such as national laboratories and other publicly supported research institutions.
} 
A second important trend reported in the OECD survey which is relevant to the discussion of technology transfer under the Climate Convention is that since its signing in 1992, laws and regulations governing an IP regime in member countries have evolved significantly. As noted in the ROK and Canada examples, the need to foster technology innovation and incubation has led to the devolvement of IPRs to non-government institutions. PROs may create incubators to foster rapid transfer of technologies to industry. These have played a key role in the growth of small research and development enterprises located in communities that have come up around the PROs. As a result, a much larger fraction of the IPRs now belong to public and private research organizations than was the case when the Climate Convention was signed and came into force in the early 1990s.

\begin{tabular}{|l|c|c|c|c|c|c|}
\hline \multicolumn{7}{|c|}{ Table 1: Ownership of IP and PROs } \\
\hline & \multicolumn{7}{|c|}{ Universities } & \multicolumn{3}{c|}{ Non-university PROs } \\
\hline & Institutions & Inventor & Government & Institutions & Inventor & Government \\
\hline Canada & $\mathrm{X}$ & $\mathrm{X}$ & & $\mathrm{X}$ & & \\
\hline $\begin{array}{l}\text { Republic of } \\
\text { Korea }\end{array}$ & $\mathrm{X}$ & & & $\mathrm{X}$ & & \\
\hline $\begin{array}{l}\text { United } \\
\text { States }\end{array}$ & $\mathrm{X}$ & $\circ$ & $\circ$ & $\mathrm{X}$ & \multirow{2}{*}{} \\
\hline
\end{tabular}

Notes: X: Legal basis or most common practice. ${ }^{\circ}$ : Allowed by law/rule but less common Source: OECD (2003).

Table 2: Number of licenses and license income, 2001 (US, Canada and the UK)

\begin{tabular}{|l|c|c|c|}
\hline Indicator & US & Canada & UK \\
\hline PROs responding to the survey & 141 & 72 \\
\hline Number of licenses yielding income & 7,562 & 453 & 483 \\
\hline $\begin{array}{l}\text { Amount of research expenditure per income } \\
\text { yielding license }\end{array}$ & $3.6 \mathrm{M}$ Euros & 2.9 M Euros & 4.3 Muros \\
\hline $\begin{array}{l}\text { Amount of license income earned for each Euro } \\
\text { spent on research expenditure }\end{array}$ & $4 \%$ & $2 \%$ & $1 \%$ \\
\hline
\end{tabular}

Source: UNICO-NUBS (2001) as reported in EC (2004)

Governments play an important role in providing funding for public R\&D programs as part of their industrial policies or science and technology development strategy. These programs are implemented either by government institutions or in joint partnership with the private sector. To promote the development of new technologies that lack short-term commercial viability, government funding and public R\&D programs are vital. In addition, governments sponsor a range of $R \& D$ that can underpin private sector investments in developing new technologies. In 
many cases, co-financing with the private sector also plays an important role. Many governments either transfer or license the patents of the publicly funded technologies to the private sector and then the transferred patents follow the rules of privately owned technologies. In the discussion below, we explore several types of technology transfer pathways for government funded R\&D programs in US, the Republic of Korea (ROK), Canada, and the United Kingdom (UK).

\section{United States. ${ }^{3}$}

Until 1980, the intellectual property derived from US government funded research was owned by the government for its use and for license to the private sector. Dissatisfied with the slow rate of technology transfer, Congress passed the Bayh-Dole Act in 1980, which gave non-profit organizations (primarily universities) and small businesses the right to retain ownership of their inventions, and to patent them, and license them to firms. The same year, the Stevenson-Wydler Technology Innovation Act made technology transfer a mission of the federal government and established an in-house Office of Research and Technology Application (ORTA) at federal laboratories.

The United States has over 700 federal laboratories; most of them are government-owned and government-operated (GOGO), and the rest are government-owned and contractors-operated (GOCO). The US Department of Energy (USDOE) owns 24 laboratories and facilities, and 22 of which are GOCOs. The DOE annual budget has been about $\$ 23$ billion of which in 2001 the R\&D budget was $\$ 4.9$ billion; it employs about 14,500 Federal and 100,000 contractor employees.

Figure 1 shows the federal R\&D funding among US agencies in 2001, and the number and income received from all active licenses, including those that were granted prior to 2001. The federal funding for R\&D amounted to about $\$ 23.2$ billion, which resulted in about 3000 active licenses in FY 2001. The various agencies collected about $\$ 60$ million of income from these licenses during that year.

\footnotetext{
${ }^{3}$ Based in part on personal communication between Cheryl Fragiadakis, Head, Technology Transfer Department, LBNL, and Jayant Sathaye and Stephane de la Rue du Can, LBNL, May 2005.
} 
Figure 1: Funding and Active Licenses
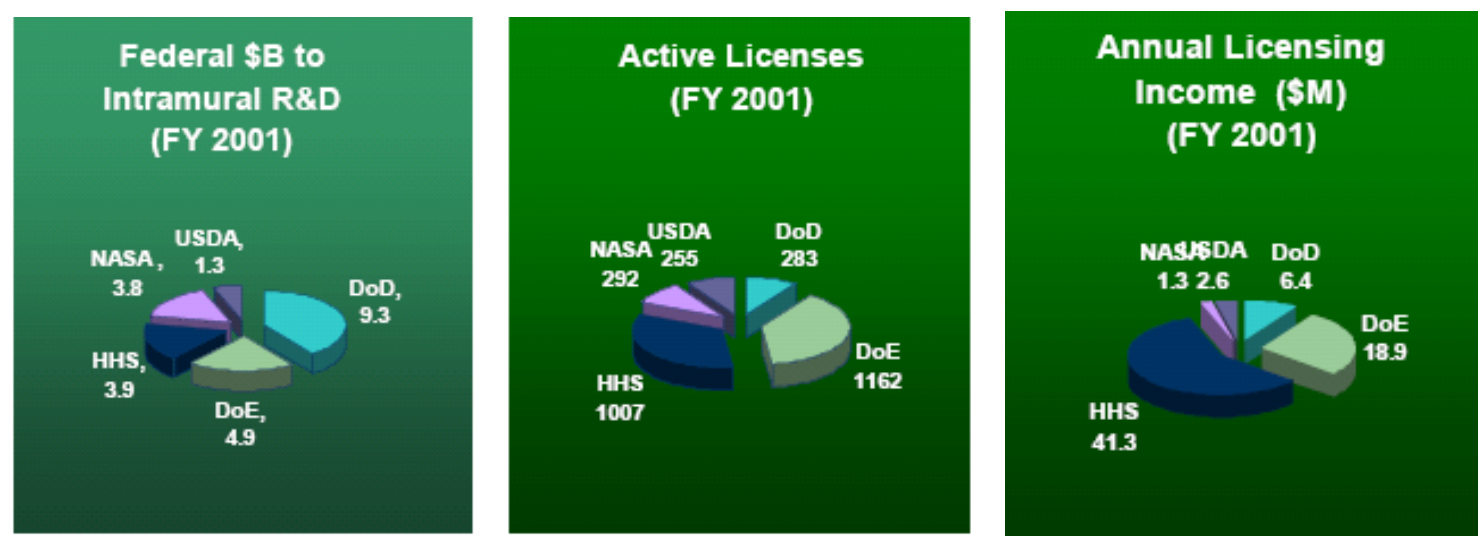

Source: Brenner (2004)

The number of patents and licenses applied for and granted in the US considerably exceeds that in the other countries. In year 2000, for instance, over 5000 patents were granted to PROs and universities, with about two-thirds going to US universities (Table 3). Licenses to these constituted a significant source of revenue, about $\$ 1.4$ billion, to universities and public research organizations (PROs).

Table 3: Patents and Licensing Activities, United States (2000)

\begin{tabular}{|l|r|r|r|r|r|}
\cline { 2 - 7 } \multicolumn{1}{c|}{} & \multicolumn{2}{|c|}{ Patents } & \multicolumn{3}{c|}{ Licenses } \\
\cline { 2 - 7 } & Applications & Grants & $\begin{array}{c}\text { Earning } \\
\text { Income }\end{array}$ & $\begin{array}{c}\text { Income per } \\
\text { license } \\
\text { (US\$) }\end{array}$ & $\begin{array}{c}\text { Gross } \\
\text { Income } \\
\text { (US\$ Mn.) }\end{array}$ \\
\hline All & 8,294 & 5,103 & $9,154 *$ & $149,334^{*}$ & $1,367.1^{*}$ \\
\hline Universities & 6,135 & 3,617 & 8,670 & 149,648 & $1,297.4$ \\
\hline PRO & 2,159 & 1,486 & 484 & 143,801 & 69.6 \\
\hline
\end{tabular}

PRO: Public Research Organizations;

* -- Estimated by the authors by adding the PRO and Universities' rows, since data were collected as running royalties, and licenses can earn income in other ways also..

Source: OECD (2003)

\section{LBNL Example:}

The Lawrence Berkeley National Laboratory (LBNL) is a national energy research laboratory that is managed by the University of California for the US Department of Energy. It is thus an example of the government-owned and contractor-operated (GOCO) approach to R\&D support and management. There are two primary ways that industry can access technologies funded by the US government at the laboratory. One approach is to seek licenses to technologies that were developed at LBNL, and another is to conduct research jointly with laboratory scientists in a public private partnership. In the second approach, DOE and industry jointly 
sponsor a research project. Costs, personnel, facilities, equipment, or research capabilities may be shared for mutual benefit. This provides industry with a way to leverage their research activities. There are four ways to protect intellectual property that result from such activities: patents, copyrights, trade marks and trade secrets. LBNL and other laboratories, and universities, are generally concerned with the first two ways to protect IP.

Patents:

An invention at LBNL is first disclosed by the inventor to the Patent Department (the local office of record), and then transferred to its Technology Transfer (TT) department. The TT department determines whether or not the Lab should seek patent protection for the invention. LBNL does not file patent applications for all invention disclosures it receives due to the high cost per application, about $\$ 10,000$ - \$20,000. It may first file a provisional patent application, which is less costly than a regular patent application and allows the Lab a year in which to decide whether to convert the provisional application to a more detailed, but more expensive, regular patent application. Once a patent application has been submitted, the TT office will promote the technology by marketing it worldwide. If a company declares interest in licensing a Lab technology, the TT office department evaluates whether the company is likely to successfully develop the technology and bring it to market.

LBNL looks for companies that are able to marshal the financial, manufacturing, marketing, and managerial requisites to successfully commercialize the technology. Once a company is found to possess the necessary capabilities, the TT licensing staff negotiates a licensing agreement. Different inventions require different licensing strategies. For example, a common strategy for a new scientific tool likely to be widely used is to license it on a nonexclusive basis (i.e., to more than one company or user). In contrast, an invention that requires a significant investment to bring it to market is more typically exclusively licensed to a single company. Licenses may also be exclusive or non-exclusive for a particular field of use or geographic region. When an agreement grants an exclusive license for the U.S. market, the licensee must substantially manufacture the technology in the U.S. The U.S. government is granted a fully paid-up, nontransferable, non-exclusive license to use the invention for government purposes only, as is the case with other federally funded inventions.

The revenue earned by the Lab from a license is typically distributed in four parts:

- $\quad$ A variable share covers the cost of patenting (attorney fees, governmental fees, etc.) 
- $\quad$ The rest is divided into three parts

o $35 \%$ for the inventor (or inventors) personally

o $15 \%$ for research in the Lab division from which the invention arose

o $50 \%$ to the Lab director to support R\&D programs, science education, and technology transfer

Copyright and Trademarks:

A copyright is sometimes used at the Lab but most of the time publication alone is adequate for the intellectual recognition of ideas. Software developed at the Lab is a special case and may be copyrighted and/or trademarked and then licensed to developers, distributors or users. One example is the EnergyPlus software for building energy simulation analysis, which issues separate licenses for different types of users.

\section{Access to licenses:}

Both exclusive and non-exclusive licenses may be accessed by US and foreign companies. The Lab does not discriminate between US and non-US entities in its selection of companies that will be permitted an exclusive or non-exclusive license. All other things being equal, however, US small businesses gets a preference, and exclusive licenses to non-US entities are referred to the Department of Energy, which in turn may consult with the office of the US Trade Representative to ensure the other country also offers US companies similar IP access and compliance with the export control regime. ${ }^{4}$

4 Export Control Review

The export control laws and regulations have several purposes: to restrict exports of goods and technology that could contribute to the military potential of U.S. international adversaries; to prevent proliferation of weapons of mass destruction; to advance U.S. foreign policy goals; and to protect the U.S. economy and promote trade goals. Attention to export controls has increased due to recent heightened concerns about national and homeland security as well as the need to prevent proliferation of weapons of mass destruction and terrorism and leaks of technology to U.S. economic competitors.

Export controls present unique challenges to universities and colleges because they require balancing concerns about national security and U.S. economic vitality with traditional concepts of unrestricted academic freedom and publication and dissemination of research findings and results. University researchers and administrators need to be aware that these laws apply to research, whether sponsored or not. (ref: Export Controls and Universities: Licensing Research?, Robert Hardy, 2004, http://206.151.87.67/docs/NACUA.doc) 


\section{Collaborative research with scientists from other institutions:}

Aside from the ways that IP transfers occur for government sponsored research at the laboratory, collaborative research with non-Lab scientists has been a time-honored tradition at most universities, including that at the Berkeley Lab. Scientific divisions at Berkeley Lab often sign Memorandums of Understanding (MOUs), Cooperative Research and Development Agreements (CRADAs), and other agreements with both US and foreign entities. Such agreements permit short and extended visits to both countries, foster collaborative research funded by either country, and often lead to new inventions, discoveries, and jointly partnered publications. LBNL's most productive outcomes have been the researcher based collaborations and/or bi-lateral relations that grow out of such partnerships. These collaborations permit better contacts, allow learning of what key people/groups are doing, establish rapport, and provide ways to work one-on-one on projects of interest. While no figures are readily available, these partnerships may lead to just as high or a larger payoff than that earned through direct licensing of technologies and software, since these include a capacity building element that might be lacking in the former type of exchange.

As is clear from the discussion of the US experience, publicly-funded research and development activities can bring together a variety of entities that contribute their input during the creative phase, and potentially share in the revenue stream following successful commercialization. However, in all cases the PROs participating in such a process are US domestic entities, whose government has provided the funds that served as the catalyst to the process.

\section{Republic of Korea: ${ }^{5}$}

The Republic of Korea recognized in the late 1990s that research in universities and public research organizations was not being adequately transferred to the commercial sector. This growing concern at the time led to major changes in the treatment of IP and its share of ownership between the government, universities, and PROs. The number of patents and licenses issued in 2001 in the ROK is shown in Table 4 below. The number of licenses earning income

\footnotetext{
${ }^{5}$ Based in part on personal communication between Yang-hoon Sonn and Jayant Sathaye, LBNL, May 2005, and Yun (2003)
} 
was 132. The income per license and the gross income in millions of US \$ is also shown in the table.

Table 4: Patents and Licensing Activities, Republic of Korea (2001)

\begin{tabular}{|l|r|r|r|r|r|}
\cline { 2 - 7 } \multicolumn{1}{c|}{} & \multicolumn{2}{c|}{ Patents } & \multicolumn{3}{c|}{ Licenses } \\
\cline { 2 - 7 } & Applications & Grants & $\begin{array}{c}\text { Earning } \\
\text { Income }\end{array}$ & $\begin{array}{c}\text { Income per } \\
\text { license } \\
\text { (US\$) }\end{array}$ & $\begin{array}{c}\text { Gross } \\
\text { Income } \\
\text { (US\$ Mn.) }\end{array}$ \\
\hline All & 1,692 & 1,018 & 132 & 28,955 & 3,822 \\
\hline Universities & 244 & 186 & 22 & 46,909 & 1.032 \\
\hline PRO & 1,448 & 832 & 110 & 25,364 & 2,790 \\
\hline
\end{tabular}

PRO: Public Research Organizations

Source: OECD (2003)

Until 2000, the ROK followed a dual system for management of IPs by PROs. One system applied to public research institutions and private universities, and another to public universities. The former could own IP arising from publicly funded research after paying a share to the government and providing compensation to individual scientists. Under the second system, public universities could not own IP arising from public research projects. IP became state property and compensation to inventors followed rules for state employees, which provided a small fixed amount and $10-30 \%$ of net license fees.

This system changed in 2000 with the enactment of the Technology Transfer Facilitation Law, which unified the IP management system for all types of PROs. A 2002 amendment to the law raised the inventor's share of the license income to $50 \%$ or more, compared to the $35 \%$ in the US/LBNL example, which provided a strong financial incentive to patent the invention. Under the amended law, a PRO is required to make use of the technology or license it to another entity, with priority going to firms that partnered in the research. The law also established a Korea Technology Trade Center which acts as a clearinghouse for PRO technology. In 2001, The Patent Law was amended to allow public universities to become legal entities in their own right, which allowed them to claim IPRs to the invention and to appropriate a portion of the license fees. Other changes allowed PROs to own equity in venture businesses by setting up publicprivate partnerships. These changes led to a significant increase in the number of technology transfer offices (TTOs) and licenses immediately after they were implemented. Kun (2003) for example reports that 20 TTOs were set up at private universities by 2002.

The implications of these laws on the process of research and technology transfer may be described through the following categorization (MOCIE 2003). A through D below refers to 
public and private entities that engage in technology research, development and transfer activities in the ROK.

A. Government owned and operated public institution, e.g., Korea Energy Management Company (KEMCO),

B. Non-profit research entity, e.g., Korea Institute of Energy Economics (KEEI)

B': For profit research entity - private research center

C. Private company partnering with B or B'

D. Private company with no partnership

Research and development may be sponsored by the government through A, which is typically a government owned entity such as the Korea Energy Management Company (KEMCO). KEMCO funds research at both non-profit (B) and for-profit (B') research, or it can fund a public private partnership $\left(\mathrm{B}^{\prime}+\mathrm{C}\right)$, or $(\mathrm{B}+\mathrm{C})$ that combine the expertise of a private company (C) with those of either B or B'. Either the government or the research institution may support work directly at a private company (D). Alternatively, A can also support research directly at D.

A non-profit research institution (B) enjoys the intellectual property right to the research sponsored by the government. IPR to research sponsored at a for-profit research institution (B'), however, belongs to the government or the sponsoring public organization (A). Internally, each research organization may have different ways to share the license fee with the individual researcher, and other offices at the research facility. Should a for-profit organization (B') succeed in commercializing the technology, it is required to pay a part of the license fee to the government. The fraction depends on the government's share of the sponsored research; 40\% where the government share is $50 \%, 20 \%$ if it is $75 \%$, etc. The non-profit research institutions' IPR is subject to considerations of national security or public purpose. The government has the right to change the IPR conditions to suit particular circumstances which may result in a different contractual agreement.

The above conditions also hold in the case of a public private partnership $(B+C)$ above, in which case, the partnership, usually the private party C, would bear the cost of the license fee. The amount to be paid to the government (through A) is $60 \%$ of that paid in the private partnership $\left(B^{\prime}+C\right)$ case. In effect, for a $50 \%$ original government sponsorship, the share of the 
license fee paid back by $(B+C)$ would be $24 \%$. Being a non-profit institution, $B$ is entitled to retain $40 \%$ of the license fee for its own use as an incentive to pursue similar future activities.

Should C choose to not make use of the commercialized technology, another firm D may make use of it, provided C voluntarily gives up its right to use the technology, is unable to or refuses to pay the license fee, or does not make use of the technology for one year.

Although the titles and organizational structures of the entities brought together through publicly sponsored research and development in Korea may differ from those in the US situation discussed earlier, the basic paradigm is the same. Specifically, the government is using public funds to facilitate creativity and synergy among its public and private sectors, while ensuring that the property rights to any resultant outcomes clearly rest in one or more of the domestic entities. That being the case, while the outcomes of these endeavors may wind up being applied all over the world, such diffusion would typically be along a pathway of licensing or royalty payments rather than use without restriction in the public domain.

\section{Canada: ${ }^{6}$}

The Canadian government provides support for $\mathrm{R} \& \mathrm{D}$ in four ways: direct grants to university researchers, procurement-based support through contracts for goods and services, intramural support through in-house basic and applied research, and industry-based support through contribution agreements (Inch J. et al. 2003). In 2001, the federal government funded CAD 3.7 billion or about 18\% of the R\&D funded in Canada. CAD 2 billion was spent on intramural R\&D compared to US $\$ 60$ billion in the US that year. The other amount went to universities, and non-profit and for-profit organizations.

Unlike the case in the United States, in Canada, federal (national) laboratories are "operated and owned" by the government (GOGO); the employees are government employees. All rights and title in the intellectual property (inventions, patents, software, copyright, trademark, etc.) developed by such employees belongs to the government. Such right and title are governed by statutes.

\footnotetext{
${ }^{6}$ Based in part on personal communication between Elmer Holt, US DOE, and Elizabeth Blackburn, NRCan, Govt. of Canada, May 2005.
} 
The government issues licenses to provide access to the intellectual property to the private sector for commercial purposes. In collaborative projects where other entities (university, private sector, other government, etc.) are involved, IP rights or sharing of rights are negotiated on a project by project basis with the above position a starting point for government employees.

In Canada (UK and Australia as well) the government, designated as the "Crown”, owns the copyright in any work that is, or has been, prepared or published by or under the direction or control of any government department, the copyright in that work belongs to the government.

Government employees include those employed in federal or provincial government departments as well as Crown corporations. Therefore, contrary to the US, copyrightable work produced by government employees and in some instances that procured by the government is not public domain work, but is protected by copyright law.

\section{Government sponsored research:}

There are different mechanisms for "sponsored" research, from departmental programs to not-for-profit organizations created by the government for such purposes, which function at arms length from the government. Some programs target funding the R-D activities of the private sector while others target universities or a mix of both.

The policy that governs such transfer of funds provides ownership in the intellectual property to the recipient of the funds. No difference is made with respect to the type of intellectual property inventions/patent vs. copyright protected material. Therefore, ownership in patents remains with the recipient of the funds. There is no automatic grant of license to the government; in certain programs, terms to grant the government a license may be included such that the license is granted only if the recipient fails to commercialize the intellectual property in a fixed period of time, which is similar to the case in the ROK. There may also be in certain arrangements (depends on the program) terms that require obtaining the written permission of the Minister of the funding department prior to the recipient assigning any of his rights in the funded research to a third party.

Certain funding arrangements may have repayment obligations and terms if the recipient has successfully commercialized the technology (IP). In other funding programs - to universities for example, the right and title will vest with the recipient - the recipient may be the university or the individual receiving the funds - all depends on the structure of the grant agreement. In most cases, the IP rights remain with the institution as the contracting authority in such arrangements. 
Sponsored research through independent corporation or not-for profit organization established by the government have essentially the same objectives - to leave the title and right in the IP to the recipient of the funds. Since most of these funds target universities and the private sector, as owners of the IP, they can license to third parties or exploit themselves the intellectual property. Again there is no difference in the type of intellectual property that arises from the work; they own all title and rights. As a rule Canada's objective is to see the results of the research commercialized, the recipient as the owner of the rights does have the freedom to use of have use of the IP as it sees fit.

As was the case in the previous discussions of the US and the ROK, publicly financed research and development activities are deliberately structured to bring forth the best from the country's public and private sectors. Part of being able to sustain such an arrangement over the long run requires sufficient incentives to keep all the relevant participants fully engaged in the process. In that regard, the Canadian example reflects similar theme present in the other countries that those that invest some combination of creative and financial resources will have clearly defined protection of any resultant intellectual property.

\section{United Kingdom (UK):}

In the period prior to the 1990s, the UK National Research Development Corporation (NRDC) obtained exclusive access to all inventions generated by universities in the UK. The Thatcher government first asked the question in the early 1980s whether the exclusive access rights that NRDC had were indeed pro- or anti-competitive. As a consequence, NRDC lost its exclusive access to university inventions, and was transformed into the British Technology Group (BTG) that has since been introduced on the London Stock Exchange. In response to the significant change in the assignment of property rights, British universities started in the late 1980s to develop their individual technology transfer and IP licensing programs (Gering 2004).

The ownership of the IP generated in publicly funded research is in general vested in UK public research organizations that actually do the research, rather than being held by a public sector; this applies to all research work carried out on behalf of the UK Government, including its Non-Departmental Public Bodies. Following the publication of the Baker Report (HM Treasury 1999), the Patent Office published guidelines to promote more effective utilization, management and exploitation of intellectual property generated in publicly funded research. 
During the fiscal year 2003-04, the HM Treasury (HMT) attributed about GBP 9 billion for public research. $45 \%$ of which was allocated to Research Councils, universities and associated bodies, 30\% for defense and 25\% to other government departments (OECD 2005).

The Research Council funding is largely allocated in grants to Universities (which are public institutions) and to Research Council Institutes, where most public sector research is carried out. The Universities come under the Department for Education and Skills (DfES) which is responsible for providing the basic infrastructure for carrying out the research; this bimodal scheme is referred to as the dual support system. The Research Councils also provide large facilities for research by university scientists, and subscriptions to international research organizations.

University control of technology transfer is relatively new in the UK, as noted above most universities did not start commercialization activities until the mid-1990s. Over the last five years significant progress has been made in terms of the number of patent applications, license deals, and spinoffs formed by universities. To assess this situation, the HMT requested a survey to examine long-term links between British business and universities (HM Treasury 2003). The context for the review was a sense that the UK performs well in terms of the academic quality of its science and technology base, but is not as good at commercializing the knowledge generated in its universities as some other countries. The report points out barriers that constrain more collaboration between public research and privates firms. Notably, that uncertainty about IP ownership is one of the main barriers to effective technology transfer and research collaboration. This particularly applies when industry contributes funding to a university research project. The US system for IP ownership provided clarity by legislating - in the 1980 Bayh-Dole Act - that US universities own any IP arising from publicly-funded research, even if it was jointly funded by industry. In the case of UK, no such clarification is made, which sometimes leads to extensive and conflicting negotiations with the private sector.

In 2002, a commission appointed by the government completed a review of ways to integrate IPR and development policy (Commission on Intellectual Property Rights 2002).It made many recommendations to the UK government (UK Government 2002). These recommendations included the provision of tax breaks to companies that license technology to developing countries, establishment of effective competition policies in developing countries, and commitments to ensure that the benefits of publicly funded research are available to all and 
open access to scientific databases. The commission also recommended making more public funds available to promote indigenous scientific and technological capability in developing countries through scientific and technological cooperation, for instance, by supporting a proposed Global Research Alliance between developing and developed country research institutions.

It is worth noting that similar to the case of the other three countries, the IPRs largely belong to the PROs that conduct the research and/or develop a technology for licensing on commercial terms to interested companies that can be either domestic or foreign entities.

\section{Summary/Conclusions:}

A review of the IPRs to research sponsored by governments in the US, ROK, Canada, and the UK reveals that governments allocate their rights (patents, copyrights, trademarks, etc.) to research organizations to a varying degree. Following the 1980 US Bayh-Dole Act, governments in many countries have taken the initiative to transfer IPRs to the recipient research institutions. This has resulted in a significant increase in the number of licenses that have provided incentives to universities and other research centers. The rules governing the use of licenses and the level of sharing of license fees amongst the inventors and institutions vary by country. Regardless of the level of sharing, it is clear that many stakeholders have an interest in continuing research, and developing technologies that may be licensed worldwide either on an exclusive or non-exclusive basis. This system of technology development and compensation to the inventors and research institutions thus provides a viable and sustainable means for continued future innovation.

The transfer of technologies for mitigation and adaptation applications across countries is one element of the Climate Convention. Since the drafting of the Convention, however, the realm of IPRs has evolved significantly. IPRs now involve many stakeholders that may not include the government. Sustaining such an arrangement over the long run requires sufficient incentives to keep all the relevant participants fully engaged in the process.

That being the case, while the technology outcomes may get applied worldwide, such diffusion would typically be along a pathway of licensing or royalty payments rather than use without restriction in the public domain. The implementation of technology transfer components 
of the Convention needs to take these realities into consideration. The evolving IPR regimes thus make the development of mechanisms for compensation of stakeholders an essential imperative.

This is not to suggest that all technology transfer requires hard monetary compensation. From the US and UK experiences with developed and developing country partners, and that of other countries too, it appears that the larger technology transfer benefit may be derived from ongoing joint research between institutions of higher learning in partnering countries. Such exchanges build capacity, foster complementary contributions by researchers from different countries, and can lead to jointly developed, and even jointly held patents and licenses. In particular applications, mechanisms of this type may be more fruitful avenues for future development and transfer of innovative technologies.

\section{REFERENCES}

Brenner R. (2004) Presentation to the FLC and DOE TPWG National Meeting. May 3-6, San Diego, CA

Commission on Intellectual Property Rights (2002). Integrating Intellectual Property Rights and Development Policy. London, UK.

European Commission (2004). Management of intellectual property in publicly-funded research organizations: Towards European Guidelines. Working paper-EUR 20915 EN

Gering. T. 2004 "Patents and Licensing by publicly funded Research Organisations in Europe an Overview”, presentation, Joint Research Center, European Commission.

Inch J. with Vernon D., Blackburn E., and Grenier M. (2003). Policy on Title to Intellectual Property Under Crown Procurement Contracts in Canada. Chapter 5 in OECD (2003).

HM Treasury (1999) Creating Knowledge Creating Wealth - Realising the economic potential of Public Sector Research Establishments.

HM Treasury (2003). Lambert Review of Business-University Collaboration, www.lambertreview.org.uk.

Metz B., Davidson O., Martens J-W, van Rooijen S., and McGrory L. (2000). Methodological and Technological Issues in Technology Transfer. Cambridge University Press, pp.466.

Ministry of Commerce, Industry, and Energy (MOCIE) (2003).Guidance for Energy-Resources Technology Development. (In Korean). MOCIE-2003-37. 
OECD (2005), “Administrative Structure of Government-funded Science and Technology in the United Kingdom”, National Science Systems, Global Science Forum.

OECD (2003) Turning Science into Business: Patenting and Licensing at Public Research Organizations, OECD, Paris. pp. 307

The UK Government Response to the Report of the Commission on Intellectual Property Rights (2002) “Integrating Intellectual Property Rights and Development Policy”

http://www.iprcommission.org

UNICO-NUBS 2001. http://www.unico.org.uk/nubs2001.htm (As reported in European Commission (2004) op cit)

Yun M. (2003) Regulatory Regime Governing of Intellectual Property of Korean Public Research Organizations: Focus on the Biotechnology Sector. Chapter 13 in OECD (2003). 